This item was submitted to Loughborough's Research Repository by the author.

Items in Figshare are protected by copyright, with all rights reserved, unless otherwise indicated.

\title{
Antecedents to export information generation: a cross-national study
}

PLEASE CITE THE PUBLISHED VERSION

http://dx.doi.org/10.1108/IMR-05-2011-0125

PUBLISHER

(C) Emerald

VERSION

AM (Accepted Manuscript)

\section{PUBLISHER STATEMENT}

This work is made available according to the conditions of the Creative Commons Attribution-NonCommercialNoDerivatives 4.0 International (CC BY-NC-ND 4.0) licence. Full details of this licence are available at: https://creativecommons.org/licenses/by-nc-nd/4.0/

\section{LICENCE}

CC BY-NC-ND 4.0

\section{REPOSITORY RECORD}

Souchon, Anne L., Belinda Dewsnap, G. Durden, C.N. Axinn, and H.H. Holzmuller. 2019. "Antecedents to Export Information Generation: A Cross-national Study”. figshare. https://hdl.handle.net/2134/18462. 


\section{Antecedents to export information generation:}

\section{A cross-national study}

Purpose - The objective of this study is to examine the factors that enhance export decisionmakers' generation of export information, using a non-linear approach and a multi-country context, and so provide export decision-makers with empirically-based guidelines on how to maximize their information acquisition efforts.

Design/methodology/approach - A broad perspective on export information generation is adopted, including marketing research, export assistance and market intelligence. The model of antecedents to information generation is tested in three studies (US, Austria, New Zealand, respectively) using structural equation modeling techniques. Multigroup and hierarchical analysis is performed to assess cross-national invariance of relevant measures, and quadratic effects.

Findings - The findings show that the predictors of export information generation vary across the three countries studied, and that many of the relationships are non-linear.

Research limitations/implications - This study contributes to the export marketing literature by developing our understanding of how exporters can develop greater knowledge of information sources on which to build export decisions, and the conditions necessary for enhanced export information acquisition activity. The findings highlight that future research should consider nonlinear relationships and the examination of the outcomes of export information generation in a cross-national setting.

Practical implications - The study findings advocate that practitioners (exporters and advisers) tailor their export information generation efforts to the different country needs.

Originality/value - This research responds to a call for more theoretically-based studies on antecedents to export information generation, concurrent with the use of more robust statistical methods.

Keywords: Exporting, Information Generation, Multigroup Analysis. 


\section{Introduction}

There is increasing evidence that export market orientation is a key differentiator between successful and less successful exporting firms (Cadogan et al, 2009). While there are several conceptualizations and operationalizations of market orientation in the generic marketing literature (e.g., Narver and Slater, 1990; Jaworski and Kohli, 1993), export market orientation is typically defined as behaviors entailing the generation and dissemination of export information, and the firm's responsiveness to that information (Murray et al., 2007). Traditionally, export market orientation has been treated as the sum of its three component behaviors, with studies examining drivers and outcomes of the construct as a whole (e.g., Cadogan et al., 2006). In contrast, research on the individual dimensions of export market orientation is still lagging despite the fact that information processing theory views the various information-related behaviors as sequential and not always perfectly aligned (Hunt et al., 2000; Clark et al., 2006). In addition, operating within its own nomological network, each of the three dimensions of market orientation has the potential to have different consequences. More specifically, it may be the case that extent of export information generation is related to extent of responsiveness to information (Theodosiou and Kaleka, 2013) rather than to performance directly. In spite of this, the typical way to measure market orientation’s impact on performance is via a single composite score which, according to Cadogan (2012), may hide the potential relationships that may otherwise be seen. Thus, examining export information generation as a separate construct constitutes a more fine-grained approach and may allow for more directly applicable recommendations that are specific to this construct. Studies adopting this more micro-level perspective are beginning to emerge in the international marketing literature (e.g., Chung, 2012; Dong et al., 2013; Sørensen and Madsen, 2012). 
The starting point for export market orientation is information generation or acquisition (Cadogan et al, 2012) (used inter-changeably in what follows). According to Kaleka and Berthon (2006, p. 1017), “the importance of [export] information acquisition is paramount, as it constitutes the input, or 'raw material' upon which subsequent processes are contingent”. Indeed, export information search and acquisition have been found to be key influences to export success (e.g., Hart and Tzokas, 1999; Koh et al., 1993; Moorman, 1995; Souchon and Durden, 2002).

So, a lack of engagement in export information generation will inevitably compromise exporters’ information dissemination and responsiveness activities. In this context, antecedents to export information acquisition constitute a critical field of research that serves to inform both theory and practice on the conditions, environments, and activities most conducive to export information generation necessary for long-term survival. However, past research in this area has suffered from a number of weaknesses.

First, work has tended to be fragmented and lack cohesion. The relevant literature is broadly split between those studies that focus on export information acquisition as a legitimate field of work in its own right (e.g., Yeoh, 2000), and those that consider export information generation only as part of export market orientation (e.g., Cadogan et al., 2009). Intriguingly, these two streams of work rarely cross over. Consequently, research on export information generation still lacks an underlying thread which could serve as a platform for the development of a theory of antecedents to information acquisition.

Secondly, a review of the literature also reveals a narrow view on the measurement of export information acquisition. Specifically, the market orientation literature typically measures the extent to which information generation takes place (Cadogan et al., 2008), and overlooks the different sources of that information. Yet, information gathered via these different sources will differ in terms of its alignment with the organization's different information needs, and 
information from different sources will vary in terms of its perceived quality (Diamantopoulos and Souchon, 1999).

Thirdly, the disparity in the quality of export information generated via different sources (Sy-Changco et al., 2005) suggests that knowledge of the drivers of those different sources would assist exporters in better targeting their efforts for improving their information collection processes. Yet, studies of export information acquisition often only report on single sources of information which are examined in isolation of other sources (e.g., Anderson, 2006; Toften and Rustad, 2005). As a result, little has been done by way of comparing different sources of export information (Souchon and Diamantopoulos, 1999), and/or the antecedent factors that drive acquisition of the different sources (Leonidou and Theodosiou, 2004).

Finally, the majority of export information acquisition studies report on single country findings (e.g., Köksal, 2005). Yet, much of the information acquisition efforts undertaken by export decision-makers will, by nature, span different countries (Samiee and Athanassiou, 1998). In addition, the export decision-maker will be in contact with information providers from a number of potential or existing target countries, and thus, needs to be in tune with the different ways in which these foreign information providers work. As explained by Morosini et al. (1998), managerial practices can vary significantly across cultures. However, without examining export information generation from a cross-country perspective, little can be known about how it varies cross-nationally or about the stability of past findings.

Against this background, the objective of this study is to examine key antecedents to export information generation and so provide export decision-makers with guidelines on how to enhance their export information acquisition efforts. Understanding what drives export information acquisition efforts can also help export information providers tailor their services to specific organizations. In addressing antecedents to export information acquisition, we examine 
those export-specific variables that characterize exporters directly, as well as the environments within which they operate. We also consider non-linear effects since this presents a more realistic and current perspective of how export information acquisition is determined within firms. For example, recent export research suggests that exporters with different levels of experience generate different types of organizational learning (Hultman et al., 2011) and that experienced exporters leverage a different set of capabilities to inexperienced exporters (Leonidou et al., 2011). In this context, as experience grows, exporters will tend to become more active in information generation to feed their export strategies (Morgan et al., 2012). However, this may happen only to the point at which they become comfortable using gut instinct and improvising in the interest of infusing speed into the decision-making process (Nemkova et al., 2012).

In so doing, we contribute to theory by adopting a broad perspective on export information acquisition covering an array of key export information sources, rather than focusing on one type of export information source. Secondly, the non-linear effects postulated and tested for are also novel in that past work on export information acquisition has tended to examine linear relationships. Thirdly, a multi-country study is used to assess cross-national invariance in the postulated relationships.

From a practical perspective, our study’s intended implications are directed both at exporters and export information providers. International information is costly to acquire. As such, knowing which types of firms prefer which types of sources may create efficiencies in the process, thus helping exporters perform better in terms of balancing costs and returns, and enabling export information providers to tailor their services more directly.

In the next section, the theoretical foundations for the study are presented, drawing from the knowledge-based view (KBV) of the firm. Central to this discussion is a consideration of different modes of export information acquisition, and a review of their key antecedents. The data 
collection process is then described, followed by an outline of measurement procedures. Findings are put forward and discussed next, and the paper is concluded by considering theoretical and managerial implications, study limitations, and directions for future research.

\section{Conceptual foundations}

In this study, Moorman's (1995, p. 320) definition of information generation as “the processes involved in bringing information about the external environment into the boundary of the organization" is adopted. Export information generation is the acquisition of information specifically relevant to export decision-making (Cavusgil, 1984a). The current interest lies in alternative modes of information generation used by exporters, rather than simply the extent of information acquisition activity, in a bid to provide a holistic picture of information acquisition activities and a comparison of alternative sources of export information. Modes of generation categorize export information sources based upon a combination of the nature of the information provided (i.e., objective vs. experiential), the degree of formality/objectivity of the acquisition process (i.e. formal vs. informal), and the location of the information (i.e. internal vs. external). Based upon past literature (Souchon and Diamantopoulos, 1996; Yeoh, 2005), three modes can be distinguished.

Firstly, export marketing research (EMR) is formal, systematic and objective (Schlegelmilch et al., 1993), and can be carried out internally (i.e., through an in-house unit/department) and/or externally (i.e., through a specialized market research agency/consultant). Secondly, export assistance (EA) encompasses market information and guidance on exporting and export marketing provided by official bodies such as government departments or chambers of commerce (Seringhaus, 1985). Finally, export market intelligence (EMI) is an informal, 
experiential export information acquisition mode that involves obtaining information from network sources, such as customers and distributors (Reid, 1984). This may be done through attendance at international trade fairs and shows, or more directly through foreign visits (e.g., Denis and Depelteau, 1985). Together, these three export information acquisition modes cover a comprehensive array of export information sources (Souchon and Diamantopoulos, 1999).

The present study is theoretically anchored in the knowledge-based view (KBV) of the firm. KBV posits that acquisition of information is key to organizational performance (Morgan et al., 2003) on the basis that experiential resources and capabilities are at the heart of securing greater export performance via market oriented behaviors (Navarro et al., 2010), including export information generation. Information, knowledge and experience represent key organizational resources and, in line with KBV (Loane and Bell, 2006; Lockett et al., 2009), it is the idiosyncratic nature of these resources when deployed that helps achieve greater competitive advantages (Fahy et al., 2000). Knight and Cavusgil (2004) outline how knowledge and information are the most important resource and provide particular advantages to firms looking to successfully internationalize. That said, competitive advantage increasingly also lies in the organizational practices that allow the firm to evolve over time, to learn, and to reconfigure its resources to match the requirements of the changing environment (Ambrosini and Bowman, 2009; Teece et al., 1997). In this way, environmental change or turbulence also plays a central role in the development of knowledge-based assets and capabilities (Lopez, 2005).

The knowledge use literature (e.g., Menon and Varadarajan, 1992) and the export information literature (e.g., Leonidou and Theodosiou, 2004; Cadogan et al., 2002, 2006) identify a range of factors that can influence an organization's information generation activity. However, in the confines of a single study, it is not feasible to investigate all possible factors, which is why specific theoretical groundings (such as KBV) are often employed to delineate relevant variables 
(Sousa et al, 2008). Driven by the KBV, a set of key determinants to export information generation is therefore presented, anchored principally in the level of analysis of the study; i.e., the export function rather than a particular export project or venture. These determinants include export-specific and environmental factors. The overall conceptual framework is shown in Figure 1.

\section{INSERT FIGURE 1 ABOUT HERE}

As Kaleka (2002) explains, experience is a critical resource in exporting and the generation of export information, a fundamental capability that together lead to improved performance. The KBV emphasizes the importance of possessing resources that are difficult to imitate in order to develop competitive advantages that will lead to enhanced financial performance (Hooley and Greenley, 2005). In this way, experiential knowledge is not easily transferable and is often unique to individuals and organizations (Johanson and Vahlne, 1977), thus conferring those who have it, with the kind of resource that can be leveraged to increase information generation capabilities and ultimately export performance.

In complex and changing environments, decisions need to be made quickly in a bid to overcome unpredictability (Cyert and March, 1963; Nemkova et al., 2012). Correspondingly, information needs to be immediately to hand so that delays in decision-making are avoided. Knowing where to acquire the most useful export information and doing so quickly (as opposed to spending time evaluating which sources of information might be better than others) will therefore be valuable within a dynamic environment (Yeoh, 2000). In this context, experience is a resource that can be harnessed to help determine where to collect export information (Seringhaus and Rosson, 1990). Thus: 
H1: Export experience is positively related to knowledge of export information sources.

Export complexity refers to the number of foreign markets the firm exports to, and is likely to be related to exposure to a greater number of sources of information (Souchon et al., 2003). In capable exporting firms, the increased experiential knowledge gained from this exposure can be used to learn which sources are the better ones, and which are to be avoided. As explained by Hultman et al. (2011), the number of foreign markets the firm is involved in will help generate different levels of knowledge. Under KBV, knowledge is a key resource which firms will seek to enhance in a bid to develop greater strategic competence (Grant and Baden-Fuller, 1995). In addition, firms that evolve in changing and complex environments (such as export environments) seek to develop capabilities for quick and versatile decision-making (Cyert and March, 1963). Thus, in these organizations, if an opportunity for knowledge enhancement presents itself, such as exposure to a variety of information sources, it will be harnessed. Therefore:

H2: Export complexity is positively related to knowledge of export information sources.

Export departments are associated with greater focus on exporting (Samiee and Walters, 1990). As a result, staff who are engaged in exporting within the structure of a formal export department tend to be more qualified, with greater education, knowledge, and motivation than export staff in other firms (Rialp and Rialp, 2006). It is therefore likely that such staff who focus on exporting and have developed extensive knowledge about exporting in general will also have developed knowledge of export information sources. It is therefore expected that: 
H3: Export specificity is positively related to knowledge of export information sources.

According to Theodosiou and Katsikea (2013, p. 77), “information sources play an important role in knowledge acquisition”. Knowledge of sources of export assistance has long been recognized as a pre-requisite for collection of export assistance information (Seringhaus, 1985, 1986;

Diamantopoulos et al., 1993). Under the same premise, knowledge of export information sources is also likely to affect collection of export marketing research and export market intelligence information (Hooley and West, 1984), since these modes of export information generation entail multiple alternative sources. Thus:

H4: Knowledge of export information sources is positively related to export information generation from a) export marketing research, b) export assistance, and c) export market intelligence.

From a KBV point of view, export experience is likely to affect export information collection. For example, Seringhaus $(1986,1987)$ explains that as exporters' experience increases, they become more interested in objective knowledge such as that provided by export marketing research (see also Cavusgil’s 1984a). It has also been argued that as companies become more established in their exporting activities they can also rely increasingly on experiential knowledge (Sood, 1981; Sood and Adams, 1985), such as that provided by export market intelligence and some forms of export assistance (Leonidou et al., 2011). Research by Souchon and Diamantopoulos (1999) also shows a positive relationship between export experience and export market intelligence generation. As it takes time to develop these contacts and networks from 
which to acquire export information (Crick et al., 1994), it makes sense that generating information from this acquisition mode increases with experience.

H5: Export experience is positively related to generation of information from a) export marketing research, b) export assistance, and c) export market intelligence.

Alternatively, the experience-information generation relationship may be curvilinear or quadratic (e.g., inverted U shaped). In other words, as organizations gain export experience, they are able to collect more and more export information, but with greater levels of experience, the export department may start relying on instinct instead to aid in making faster decisions (Moorman and Miner, 1998; Vyas and Souchon, 2003; Nemkova et al., 2012). Thus:

H6: The relationship between export experience and export information generation from a) export marketing research, b) export assistance, and c) export market intelligence is invert-U shaped.

The export context is characterized by a complex market environment (Lopez, 2005; Cavusgil, 2007). Many exporters quickly develop large portfolios of export markets (McNaughton, 2003), which can complicate their export activities, and multiply the environmental turbulence and uncertainty experienced. Yet, at the same time, this greater exposure to new foreign markets is part of what has allowed current exporters to thrive in the global economic crisis; exporters have proven more resilient to the economic downturn than other firms (Department of Business Enterprise and Regulatory Reform, 2008), because exposure to new ideas from abroad strengthens export knowledge and can help maintain competitive advantages (Business Link, 
2010). The greater the complexity of export operations, the greater the innovation potential, and if exporters harness this potential, the more information they will be generating to secure relevant knowledge. The consequence of this is that information is then more likely to be collected from more than one source in order to maximize the accuracy of decisions (Cadogan et al., 2008). In this context, Diamantopoulos et al. (1990) reveal that companies that acquire information via export marketing research tend to be active in more export markets and a larger number of regions. This finding was interpreted as indicating that a high number of export markets may render the sole reliance on experiential knowledge inadequate. Collection of export assistance information is also likely to increase with export complexity as companies which repeatedly target new export markets require the fast acquisition of country/market-specific export knowledge and experience which export assistance bodies aim to provide (Gençtürk and Kotabe, 2001). Furthermore, exporters tend to rely on personal contacts for information generation (Anderson, 2006), and it is likely that the greater the number of country markets they are involved in, the greater the number of contacts they will have developed overall.

H7: Export complexity is positively related to generation of information from a) export marketing research, b) export assistance, and c) export market intelligence

The number of markets a firm exports to (export complexity) is sometimes viewed as a form of export experience, then labelled scope of exporting (Hultman et al., 2011). As explained above, with greater complexity or scope comes greater need to generate information about a growing number of markets. However, ever increasing amounts of complexity-induced information can lead to information overload. Information overload is reached when the amount of information obtained exceeds people’s ability to process this information (Hunter and Goebel, 2008). 
According to Vyas and Souchon (2003), export information overload can lead to information avoidance. In turn, given the high cost of generating international market information (Souchon and Diamantopoulos, 1999), it is not likely that exporters would devote financial resources to collecting information they do not plan to use. A reasonable assumption is therefore that information avoidance will be related to a reduced extent of export information generation efforts. We can see in this context that export complexity would only be positively related to export information generation up to a point. Once information processing capability has been reached, exporters would start to rely on their instincts, and export information generation activities would start to decline. Thus:

H8: The relationship between export complexity and export information generation from a) export marketing research, b) export assistance, and c) export market intelligence is invert-U shaped.

Not all exporting firms have an organizational structure that includes a separate export department. In the KBV framework, export departments are considered a crucial resource in general (Navarro et al., 2010), and also more specifically for organizing systematic generation of export market knowledge (Rialp and Rialp, 2006). The presence of a separate export department within an organization - referred to as 'export specificity' - tends to reflect the company’s commitment to, and focus on, its exporting operations (Samiee and Walters, 1990) and, relatedly, to increased export information acquisition (Cavusgil, 1984a; Koh, 1991; Souchon and Diamantopoulos, 1999). It has also been found that more proactive exporters (those with greater corporate commitment to exporting and therefore more likely to be structured in an exportspecific way) tend to use a wider breadth of sources (Samiee, et al., 1993). Looking more 
specifically at individual modes of export information generation, an early study by

Diamantopoulos et al. (1990) shows that companies that have a separate export department tend to collect more marketing research information than those that do not. It could be that the information needs of export-specific organizations are more specialized, requiring targeted and formal export information. It is also likely that the existence of an export department is the result of more investments into export activities, with more financial resources being made available for the generation of expensive market research information. Secondly, Leonidou et al. (2011) state that internal (organizational and managerial) factors are crucial determinants to the awareness and use of export assistance. Staff whose job description it is to focus on export matters will be aware of export assistance sources, and while they may not use them to the exclusion of others, they are likely to tap them to triangulate other sources (c.f., Samiee et al., 1993). In addition, it has been said that "export marketing departments must provide manufacturing divisions with timely market-demand information that minimizes the costs incurred” (Zhang et al., 2008, p. 111). Informal export intelligence sources allow for fairly accurate pictures of target markets, and frequent exchange of information at minimal cost (Kaleka, 2011). Thus:

H9: Export specificity is positively related to export information generation from a) export marketing research, b) export assistance, and c) export market intelligence.

Hultman et al. (2011) classify the ratio of export sales to total sales (export dependence or intensity) as a dimension of export experience, and indicate that this will be related to knowledge and learning. However, knowledge and learning cannot be developed without having obtained relevant information in the first place. In addition, greater dependence on the export function or export markets for total sales turnover will inevitably be associated with greater commitment to 
achieving export goals. In turn, this commitment is linked to "the presence of a foreign market information collection system [that] helps reduce uncertainty in the development of export marketing and thus engenders the development of a more proactive attitude in approaching exporting opportunities” (Navarro et al., 2010, p. 46). Thus, we expect that:

H10: Export dependence is positively related to export information generation from a) export marketing research, b) export assistance, and c) export market intelligence

That said, with a greater reliance on exporting for firm success, export decisions become increasingly important to the organization, and the need to be competitive in export markets intensifies (Morgan et al., 2012). In this context, exporters tend to require more agile and flexible decision-making processes to keep a step ahead of the market and competition, and will employ more innovative decision-making techniques to do so (Filipescu et al., 2013). A common occurrence is for these exporters to improvise in a bid to respond to, and even anticipate, customer needs and competitors' moves (Nemkova et al., 2012). Improvisation, by definition, is acting on the spur of the moment (Moorman and Miner, 1998), in which context time spent on information search will be reduced. We therefore anticipate that while export dependence will be positively related to generation of export information, this will only be up to the point at which exporters feel the need for faster, more agile decision-making that allows them greater competitiveness. Thus:

H11: The relationship between export dependence and export information generation from a) export marketing research, b) export assistance, and c) export market intelligence is invert-U shaped. 
The environment plays a determining role in how decisions are made and whether or not they are likely to be successful (Ambrosini and Bowman, 2009). Environmental turbulence is also a strong determinant of decision-maker uncertainty (e.g., Glazer and Weiss, 1993; Yeoh, 2000). To reduce such uncertainty, export managers are likely to collect more information than those operating in more stable environments with lower levels of uncertainty (Leblebici and Salancik, 1981; Menon and Varadarajan, 1992). Thus, we expect that:

H12: Environmental turbulence is positively related to export information generation from a) export marketing research, b) export assistance, and c) export market intelligence

Notwithstanding this, an increasingly dynamic export environment is going to require the making of fast decisions that afford competitiveness and first-mover advantages (Wang, 2009). As explained by Cadogan et al. (2006), turbulent market conditions exert pressure on firms to generate export information quickly. Evidence of the impact of environmental turbulence on use of different sources of export information is scarce. However, looking first at export marketing research, this is not a mode of export information generation that provides fast access to information: it is formal and systematic, and requires considerable skill, resources, and time (Cavusgil, 1985). Secondly, export assistance information tends to be criticized for often being out of date (Souchon and Diamantopoulos, 1997), a fact which is unlikely to make its generation desirable when the environment warrants timely information. Finally, informal export market intelligence sources are active players within the relevant markets and industries (Diamantopoulos and Souchon, 1996; Kaleka, 2011), and while they are more likely to provide current information, the time it takes to network to access this information will inevitably exceed 
that needed to make spur of the moment decisions required in turbulent environments (Nemkova et al., 2012). It is therefore expected that:

H13: The relationship between environmental turbulence and export information generation from a) export marketing research, b) export assistance, and c) export market intelligence is invert-U shaped.

\section{Methodology}

\subsection{Data collection}

The objective of the study is to assess antecedents to export information generation and to shed light on the cross-national stability of the proposed relationships. To this end, data was collected from three industrialized countries to optimize construct (conceptual) equivalence (Craig and Douglas, 2000). The three countries were the USA, Austria, and New Zealand, spanning three continents and two cultural clusters (Anglo-Saxon and Germanic - see House et al. [2004]). A mail survey was used to aid data collection equivalence (Hult et al., 2008). The survey questions were initially developed on the basis of a literature review, exploratory interviews with export decision-makers, and two separate pilot studies. Questionnaires were sent from universities within each of the three different countries to domestic nationals. Samples sizes for the US, Austria and New Zealand are, respectively, $\mathrm{N}_{\mathrm{US}}=161, \mathrm{~N}_{\text {Austria }}=220$, and $\mathrm{N}_{\text {New Zealand }}=239$. Response rates for each country were, respectively, $9 \%$ in the US, $17 \%$ in Austria, and $46 \%$ in New Zealand. These are commensurate with other export studies (e.g., Samiee and Walters, 
2002; Williams, 2003; Lukas et al., 2007). For descriptive information about the three samples, please see Appendix 1.

The adopted survey approach mirrors other international marketing studies (Bello, Katsikeas and Robson, 2010) in that one key informant (the main export decision-maker) was used rather than multiple informants from each firm . When conducting marketing research this approach tends to have low susceptibility to bias (Rindfleisch et al., 2008). To safeguard data quality, specific attention was paid to selecting respondents who were the most knowledgeable about export decisions in their firms. Moreover, t-tests on all key constructs were performed to assess non-response bias, by comparing early and late respondents using (Armstrong and Overton 1977) which revealed no differences. Telephone follow-ups were also conducted in order to assess eligibility of non-respondents. Ineligibility (e.g., companies not exporting) was a common cause of non-response, further suggesting absence of bias. Potential common method variance was ascertained using the Harman single-factor test in exploratory factor analysis, following Podsakoff et al. (2003).

\subsection{Construct Measurement}

Three previously validated scales taken from Souchon and Diamantopoulos (1999) were used to measure export information generation via export marketing research, export assistance, and export market intelligence, and were treated as formative variables ${ }^{1}$.

\footnotetext{
${ }^{1}$ Cadogan and Lee's (2013) guidelines for modeling formative endogenous variables were followed. However, the individual items were not treated as separate endogenous variables since no differences were expected in the predicted relationships between the antecedent variables and each generation indicator. In Appendix 4 we provide correlation matrices and descriptive information for the variables.
} 
Jaworski and Kohli’s (1993) multi-item scales of environmental turbulence were used, with competitive intensity, market dynamism and technological turbulence measured as three separate constructs. Knowledge of export information sources was taken from Vernon and Ryans (1975), export experience was measured as per Leonidou and Katsikeas (1997), export specificity as per Samiee and Walters (1990), and export complexity followed Schlegelmilch et al.’s (1993) operationalization (see Appendix 2 for measurement details). In addition, we included a measure of full-time employees into the analysis to control for company size (e.g., Samiee and Walters, 1990).

To ensure comparability of findings across the three country samples, assessment of measure invariance ("whether or not, under different conditions of observing and studying phenomena, measurement operations yield measures of the same attribute”, see Horn and McArdle, 1992, p. 117) plays a crucial role (e.g., Mullen, 1995). In the words of Byrne et al. (1989, p. 456), an important assumption in cross-national research “is that the measurement and the structure of the underlying construct are equivalent across groups”.

First, in order to aid instrumentation equivalence identical item content across countries was included in the research instrument (Cavusgil and Das, 1997; Poortinga, 1989).

Second, attention was paid to calibration and translation equivalence. To ensure these two types of equivalence, the same 5-point frequency scales were used across countries where use of such a number of scale points is commonplace (e.g., Sinkula, 1990). Translation equivalence for the Austrian sample was ensured by translating questions into German and back into English using back-translation procedures recommended by Brislin (1986).

Third, Steenkamp and Baumgartner (1998) highlight the necessity of hierarchically achieving configural, metric, and factor variance invariance when assessing structural relationships among a nomological network of variables across different samples. In terms of 
configural invariance, Steenkamp and Baumgartner (1998, p. 80) explain that "the items comprising the measurement instrument should exhibit the same configuration of salient and nonsalient factor loadings across countries”. No assumption as to the magnitude of the factor loadings is made at this stage. Next, metric invariance is assessed by constraining the factor loadings to be equal across countries, so that different scores across countries can be meaningfully compared. Finally, factor variance invariance, whereby the factor variances are constrained to be equal across countries, is important for evaluating the factor structures and homogeneity of factor scores (Steenkamp and Baumgartner, 1998). Next, two-stage structural equation modeling was conducted, following the procedures outlined by Anderson and Gerbing (1988).

\section{Results and Discussion}

\subsection{Measurement invariance}

Multi-sample, confirmatory factor analysis (CFA) revealed full configural, partial metric, and full factor variance invariance for the three multi-item scales capturing environmental turbulence (see Table 1). Next, composite reliabilities and average variance extracted for each of these three constructs were calculated, and proved above recommended thresholds. Discriminant validity was assessed by comparing average variance extracted with squared inter-construct correlations (with the latter being smaller than the former in most instances, as per Fornell and Larcker’s (1981) recommendation), see Appendix 3.

INSERT TABLE 1 ABOUT HERE 


\subsection{Determinants of export information generation}

The structural model presented in Figure 1 was tested using maximum-likelihood estimation in LISREL 8.71, a multigroup analysis (Jöreskog and Sörbom, 1993) for invariance testing of the structural paths, and a hierarchical approach owing to the quadratic effects tested for. The structural model was tested hierarchically by first constraining all paths to be equal across the three country samples, and without quadratic relationships (see Table 2). With paths still constrained, the model was then tested with quadratic relationships. While the fit of the first model was good, this second model delivered an improvement in fit. (The reduction in chi-square on moving from model 1 to model 2 is significant, indicating that this model is a better fit to the data than the constrained model without quadratics). The next step still with quadratic relationships (Model 3) was to allow the model to run free (fully variant). This again produced a better model fit. After this, the relationship paths were freed one by one and the results compared with Model 2. A total of 49 models were run with each individual path freed in turn. The final model incorporated quadratic relationships and only those paths that proved variant across the three countries. This is reported as Model 4 in Table 2. This equates to cross-national differences in the relationships between export information acquisition modes and their postulated antecedents.

\section{INSERT TABLE 2 ABOUT HERE}

The path estimates and t-values of the model's dependent variables are presented in Table 3. First, the $\mathrm{R}^{2} \mathrm{~s}$ for knowledge of export information sources (.17 in the US, .28 in Austria and .20 
in NZ), export marketing research (.30 in the US, .38 in Austria, and .28 in New Zealand), export assistance (.42 in the US, .30 in Austria, and .22 in New Zealand), export market intelligence (.69 in the US, .56 in Austria, and .54 in New Zealand) show that acceptable proportions of the variance in the dependent variables are explained. Second, the results show that antecedents to knowledge of export information sources are invariant across all 3 countries, but that, with a few exceptions, the extent to which antecedents are related to export information generation from export marketing research, assistance, and intelligence differs across the US, Austria, and New Zealand.

\section{INSERT TABLE 3 ABOUT HERE}

In summary, all hypothesized antecedents (export experience, complexity and specificity) have an impact on knowledge of export information sources regardless of the country studied (thus supporting $\mathrm{H} 1$, H2, and H3).

Unsurprisingly, knowledge of export information sources was found to be strongly and positively related to all three export information generation modes in all three countries (thus also supporting H4), meaning that when exporters have acquired this knowledge, their generation activities grow. That said, these knowledgeable exporters appear to be collecting more export assistance information than export market intelligence. Thus, export assistance bodies should tailor their offerings to those firms that have knowledge, not just to those that seek it.

On the other hand, we find export experience to be related to export market intelligence only in Austria, and also in the opposite direction to that expected (i.e., it is a negative relationship). Thus, H5 is not supported. Had positive relationships been uncovered between any other mode of export information generation in Austria, we might have argued that the more 
experienced exporters rely on alternative modes. But this is not the case. The negative finding therefore seems to suggest that experienced exporters in Austria do not tend to collect more information. They may, instead, make more intuitive decisions, potentially relying on improvisation instead of information-based planning approaches (e.g., Nemkova et al., 2012). For those non-significant links, it could be that the relationship is positive in some circumstances and negative in others, or strong versus weak in different conditions. One such moderator might be the destination country. More specifically, export experience might be strongly positively related to export information generation all other things being equal, but if information is not readily available/accessible in some target export markets (Yeoh, 2005), export experience will have no effect on actual information collection. This may be the case when exporting to China, for example, where up-to-date information is often lacking or unavailable. Industry might also be a moderator as buyers in some industries might be very similar across markets, in which case the exporter may not perceive the need for market-specific information. In addition, cultural distance between host and home country may also act as a moderator, with organizations exporting to culturally similar countries not needing to acquire quite so much export information when experience is already high.

Similarly, the quadratic effect that was postulated between experience squared and export information acquisition was not supported (H6) - export experience squared appears unrelated to any sources in any of the countries studied. As suggested above, moderators may come into play here to explain the lack of a significant finding. For example, it could be that the relationship between experience and information generation is flat, and moderated by host country or industry.

The next hypothesis (H7) was partially supported, with the greater the export complexity, the greater the generation of export information in the form of export assistance and export 
market intelligence, but not export marketing research. Exporters who are involved in a greater number of export markets require more information from these two sources than those who are not. Export assistance organizations should therefore tailor their programs to those companies that have a diversified portfolio of markets, for example, offering help in managing ranges rather than individual markets, or providing one-stop ports for a wider variety of export markets. The importance of personal networks is also highlighted by the finding that export complexity is related to greater export market intelligence generation. Managing a network is tricky at the best of times, but cumulating contacts in a wide variety of countries necessarily entails developing knowledge of a variety of foreign cultures. To this end, and to maximize the export information collected when complexity is high, language skills should be honed, and the self-reference criterion studied (Lee, 1966). With regards to export marketing research, and in light of H8, it is almost certain that the relationship is not linear but quadratic, as we explain below.

With H8 we had hypothesized that the complexity-information generation relationship would be curvilinear or quadratic (e.g., inverted U shaped). This hypothesized relationship held for export marketing research and export assistance modes, but not export market intelligence. The linear relationship showed that as the number of export markets increases, intelligence on these markets increases proportionately. As company personnel or their de facto agents operate in markets, we might naturally expect that they would simply gather more intelligence in the process of operating in these markets.

Export specificity is positively associated with generation of export information from export marketing research and export market intelligence, and equally in all countries. Where export assistance is concerned, a significant effect can be found in the US and Austria (though not in New Zealand) (thus providing some strong support for H9). Companies in New Zealand 
are typically smaller (see Appendix 1). By the time they have grown to warrant a separate export function, they may well have outgrown the need for export assistance.

Export dependence was only found to be positively and significantly related to export market intelligence in the US and New Zealand (thus partially supporting H10). The first noticeable thing is that the relationship with export marketing research is invariant and nonsignificant across countries and that this is true of both the linear and the quadratic effect. This may indicate that regardless of the proportion of total sales turnover derived from exporting, exporters generate export marketing research information just as frequently. The same applies to the linear relationship between export dependence and export assistance generation. In this latter case, this appears to be because the relationship is, in fact, curvilinear at least in Austria and New Zealand, as explained below.

Specifically, in Austria, levels of export dependence drive higher levels of export assistance generation up to a point; beyond this level and in line with expectation (H11), generation of export assistance decreases. In New Zealand, however, the reverse appears to be the case (against expectations). Thus, companies with low dependence on exporting may be aiming to grow given the small size of the domestic market in New Zealand. In turn, export assistance bodies are often government-based, with the aim to grow the balance of payments. They will have the same objective as these companies: to grow exporting. Middle levels of export dependence have established a level of exporting and may have shifted their information source preferences to export market intelligence as demonstrated by the linear relationship found between export dependence and export market intelligence generation. Thus, and interestingly, the findings regarding the quadratic effect postulated between dependence and export information generation paint a mixed picture. Where export market intelligence is concerned, H11 is supported with an invert-U shaped relationship in all three countries. That said, with regard to 
export assistance, the expected invert-U shape was found in Austria but to be U-shaped in New Zealand, and non-significant in the US. There is no relationship found at all in respect of export marketing research.

Where environmental turbulence is concerned, technological turbulence was found to be equally and positively related to export marketing research acquisition in all countries, but not to export assistance or export market intelligence in any country. Thus, information on technological advances appears to be acquired mainly from formal and systematic channels. Competitive intensity was only related to export market intelligence generation in Austria, while market dynamism was also related (positively) to export market intelligence generation but in New Zealand. Thus, there is partial but limited support for H12. It may therefore be the case that many exporters operating in a turbulent market and competitive environments rely on export memory (Sy-Changco et al., 2005) or improvisation (Akgün et al., 2007), rather than freshly acquired information. Much of the improvisation literature makes a case for improvised decisionmaking when the organization is responding to a crisis or is under threat, such as when the environment is turbulent (Chelariu et al., 2002). Alternatively, environmental turbulence was also posited to be related to export information generation quadratically (as an invert-U shape relationship). However, we only found support for this expectation in respect of competitive intensity and its relationship to export market intelligence. Nevertheless, this relationship held equally in all three countries (thus partially supporting H13). Thus, with regards to environmental turbulence, the first observation is that none of its dimensions are related to export assistance in any country, whether linearly or quadratically. This could be because there are reasons to collect export assistance information when the environment is both stable and dynamic. In stable environments, greater levels of export planning, and therefore information seeking to support the plans, take place (Nemkova et al., 2012). Equally, in dynamic environments, the rate of 
environmental change requires that exporters keep abreast of these changing conditions. The fact that this would apply only to export assistance makes sense given the cost-efficiency of this type of mode (and the amount of information needed in dynamic environments). Conversely, one might also argue that in stable environments, little information is needed and its collection is counter-productive (Cadogan et al., 2009), and that in dynamic environments, export assistance information becomes too quickly outdated to be of any use; thus in both circumstances, export assistance would be avoided. Both these competing theories would explain the non-significant findings here. Secondly, with regards to export marketing research, we found an invariant, positive and linear relationship with technological turbulence, as expected. Competitive intensity and market dynamism appeared unrelated both linearly and quadratically to export marketing research. The explanation outlined above in respect of the turbulence-export assistance relationship could hold here; that is, there could be justification for collecting export information via export marketing research when the technological and competitive environments are both stable and dynamic. The fact that no significant relationships were found between technological turbulence and export market intelligence is explained by the significant relationship found in all countries between this environmental factor and export marketing research. Specifically, decisions that require an understanding of changes in technology, are more likely to be supported by research executed formally (export marketing research) rather than via the informal route of export market intelligence. The minimal support for the hypothesized linear relationship between market dynamism and export market intelligence appears to be because as demonstrated by the significant relationship for all countries here, this relationship is actually curvilinear.

\section{Contributions and conclusions}


In meeting the objectives of this study to examine key antecedents to export information generation in a multi-country context, we offer theoretical and practitioner contributions and propose a number of further research avenue.

This study contributes to export theory by addressing Leonidou and Theodosiou's (2004, p.31) call in respect of the need for more theoretically based and comprehensively operationalized studies that explicate antecedents to export information generation while employing "more robust statistical methods". Central to this contribution is the broad perspective on export information acquisition to include a range of key export information sources. From our findings, it is clear that future research should conceptualize and test relationships using separate measures of export information generation. Second, and with regard to KBV as the study's theoretical base, we demonstrate how experiential resources and capabilities are integrally linked to knowledge of export information sources (in all countries studied), and how, in turn, these same resources relate to the separate sources of information generation. The novel way in which we test for, and find non-linear effects on, export information acquisition also suggests that future research should examine non-linear relationships. At the heart of cross-cultural studies is, on the one hand, the desire to find evidence that results can be generalized across international boundaries and, on the other, the need to understand any culture-specific differences (Hult et al. (2008, p.1). The multi-country focus of our study therefore represents a final, important academic contribution. Specifically, our findings indicate that the predictors of export information generation vary across the three countries studied and highlight that future export research should consider the adoption of a cross-national approach. Furthermore, with much of the variance in export information generation explained, our study provides a detailed understanding of what drives exporters to gather information. 
From a practitioner perspective, understanding where to derive export knowledge, and having better insights into what types of firms prefer which types of export information generation and what drives such acquisition efforts can, collectively, help firms understand which sources might be most appropriate for their individual needs and overall support their optimal management of export marketing information. In this regard, the fact that all hypothesized antecedents - export experience, complexity and specificity - are positively associated with knowledge of export information sources irrespective of country studied offers a key contribution to exporters in their management of export personnel and export structures. For example, where export experience is lacking, practitioners should look to recruit either staff experienced in exporting practice in general or with experience of specific export markets. Firms who are exposed to a greater number of export markets are better-placed to possess the knowledge of export information sources. However, complexity would undoubtedly bring its own challenges in terms of information management, particularly in terms of organizing and disseminating the knowledge internally. This, in turn, would suggest that such firms should pay careful attention to the design and management of their export marketing information systems. Finally, the fact that those firms who are organized to include a separate export marketing function are better placed to understand the export information sources available is a call for those firms who are in a position to structure to include a separate export department, to do so.

These insights also help export information providers (such as government departments, as well as market research agencies) tailor their services to specific organizations. Government departments offering export promotion in the form of information, or indeed freelance export consultants, can now tailor their advice to suit individual firms’ circumstances. 
The study is not without limitations. These issues are discussed below and suggestions are made as to how they can be addressed by future research.

While care was taken not to postulate causal relationships which are difficult to test in cross-sectional designs, causality was implied. Yet, reverse causal ordering may be equally valid. For example, with increased export information, the organization may decide to penetrate new export markets quicker, thus increasing export complexity and, similarly, may be driven to more quickly establish a separate export function. A longitudinal design may allow future researchers to tease out the causal ordering (or indeed cyclical and recursive effects) of the variables studied.

In addition, while this survey focused on three developed countries, no account of the potential cultural effects was taken. A future researcher may wish to increase the sample base by examining the drivers of export information generation in collectivist countries such as China, where, for example, shared knowledge may accumulate faster and drive faster information generation behavior.

As noted in the discussion of results, equivocal findings may be the result of method and conceptualization. For example, the equivocal results for the experience-acquisition hypothesis are a call for future research to consider moderating effects.

Finally, although empirical research has been published reporting the effects of export information generation on export performance (Murray et al, 2007), no study to date has compared the outcomes of the different acquisition modes. Indeed, given the current results, it may be that export marketing research information, for example, does not yield outcomes as favorable as export market intelligence. 


\section{References}

Akgün, A.E., Byrne, J.C., Lynn, G.S. and Keskin, H. (2007), "New product development in turbulent environments: Impact of improvisation and unlearning on new product performance”, Journal of Engineering and Technology Management, Vol. 24 No. 3, pp. 203-230.

Ambrosini, V. and Bowman, C. (2009), "What are dynamic capabilities and are they a useful construct in strategic management?” International Journal of Management Reviews, Vol. 11 No. 1, pp. 29-49.

Andersen, P.H. (2006), “Listening to the global grapevine: SME export managers’ personal contacts a vehicle for export information generation”, Journal of World Business, Vol. 41 No. 1, pp. 81-96.

Anderson, J.C. and Gerbing, D.W. (1988), "Structural equation modeling in practice: A review and recommended two-step approach”, Psychological Bulletin, Vol. 103, pp. 411-423.

Armstrong, J. and Overton, T.S. (1977), “Estimating nonresponse bias in mail surveys”, Journal of Marketing Research, Vol. 14, pp. 396-402.

Bello, D. C., Katsikeas, C. S., and Robson, M. J. (2010), “Does accommodating a self-serving partner in an international marketing alliance pay off?”, Journal of Marketing, Vol. 74, No. 6, pp. 77-93.

Brislin, R.W. (1986), “The Wording and Translation of Research Instruments”, in Lonner. W.J. and Berry, J.W. (Eds.), Field Methods in Cross-Cultural Research, Sage: Newbury Park, pp. 137-164.

Cadogan, J.W. (2012), “International marketing, strategic orientations and business success: Reflections on the path ahead”, International Marketing Review. Vol. 29 No. 4, pp. 340- 
348.

Cadogan, J. W., Cui, C. C. Morgan, R. E. and Story, V. M. (2006), “Factors facilitating and impeding the development of export market-oriented behavior: A study of Hong Kong manufacturing exporters”, Industrial Marketing Management, Vol. 35, pp. 634-647.

Cadogan, J.W., Diamantopoulos, A. and Siguaw, J. A. (2002), “Export market-oriented activities: Their antecedents and performance consequences”, Journal of International Business Studies, Vol. 33 No. 3, pp. 615-626.

Cadogan, J.W., Souchon, A.L., and Procter, D.B. (2008), “The quality of market-oriented behaviors: Formative index construction and validation”, Journal of Business Research, Vol. 61 No. 12, pp. 1263-1277.

Cadogan, J.W., Kuivalainen, O. and Sundqvist, S. (2009), “Export market-oriented behavior and export performance: Quadratic and moderating effects under differing degrees of market dynamism and internationalization”, Journal of International Marketing, Vol. 17 No. 4, pp. 71-89.

Cadogan, J.W, Sundqvist, S., Puumalainen, K., and Salminen, R.T. (2012), “Strategic flexibilities and export performance”, European Journal of Marketing, Vol. 46 No.10, pp. 1418-1452.

Cadogan, J.W. and Lee, N.J. (2013), Improper use of endogenous formative variables, Journal of Business Research, Vol. 66 No. 2, pp. 233-241.

Cavusgil, S.T. (1984a), “International marketing research: Insights into company practices”, Research in Marketing, Vol. 7, pp. 261-288.

Cavusgil, S.T. (1984b), "Differences among exporting firms based on their degree of internationalisation”, Journal of Business Research, Vol. 12, pp. 195-208.

Cavusgil, S.T. (2007), “Preface”, Advances in International Marketing, Issue 18, pp. xv-Xv. 
Cavusgil, S.T., and Das, A. (1997), "Methodological issues in empirical cross-cultural research: A survey of the management literature and a framework”, Management International Review, Vol. 37 No. 1, pp. 71-96.

Chelariu, C., Johnston, W.J. and Young, L. (2002), "Learning to improvise, improvising to learn: A process of responding to complex environment”, Journal of Business Research, Vol. 55, pp. 141-147.

Chung, H.F.L. (2012), “Export market orientation, managerial ties, and performance”, International Marketing Review, Vol. 29 No 4, pp. 403-423.

Clark, B.H., Abela, A.V., and Ambler, T. (2006), “An information processing_model of marketing performance measurement”, Journal of Marketing Theory \& Practice, Vol. 14 No. 3, pp. 191-208.

Craig, C.S., and Douglas, S.P. (2000), International Marketing Research, New York: Wiley.

Crick, D., Jones, M., and Hart, S. (1996), "International marketing research activities of UK exporters: an explanatory study”, Journal of Euromarketing, Vol. 3 No. 2, pp. 7-26.

Cyert, R.M., and March, J.C. (1963), Behavioral Theory of the Firm, Englewood Cliffs. NY: Prentice Hall.

Denis, J-E., and Depelteau, D. (1985), „Market knowledge, diversification and export expansion”, Journal of International Business Studies, Fall, pp. 77-89.

Department of Business Enterprise and Regulatory Reform (2010), http://www.businesslink.gov.uk/bdotg/action/detail?type=ONEOFFPAGE\&itemId=108266 0109. 
Diamantopoulos, A. and Siguaw, J.A. (1996), “Determinants of export marketing research evaluations: An exploratory study of firms in the UK”, Proceedings of the Academy of Marketing Science Conference.

Diamantopoulos, A., and Souchon, A.L. (1996), “Instrumental, conceptual, and symbolic use of export information: An exploratory study of UK firms”, in Cavusgil, S.T. (Ed.), Advances in International Marketing, Jai Press, Greenwich, CT.

Diamantopoulos, A., Schlegelmilch, B.B. and Allpress, C. (1990), "Export marketing research in Practice: A comparison of users and non-Users”, Journal of Marketing Management, Vol. 6 Winter, pp. 257-273.

Dong, X., Hinsch, C.A., Zou, S., and Fu, H. (2013), “The effect of market orientation dimensions on multinational SBU's strategic performance - An empirical study”, International Marketing Review, Vol. 30 No 6, pp. 591-616.

Fahy, J. and Hooley G., Cox, T. (2000), “The development and impact of marketing capabilities Filipescu, D.A., Prashantham, S., Rialp, A., and Rialp, J. (2013), “Technological innovation and exports: Unpacking their reciprocal causality”, Journal of International Marketing, Vol. 21 No. 1, pp. 23-38.

Fornell, C., and Larcker, D.F. (1981), “Evaluating structural equation models with unobservable variables and measurement error”, Journal of Marketing Research, Vol. 8 No. 1, pp. 39-50. Gençtürk, E.F. and Kotabe, M. (2001), “The effect of export assistance program usage on export performance: A contingency explanation”, Journal of International Marketing, Vol. 9 No. 2, pp. 5l-72

Grant, R.M. and Baden-Fuller, C. (1995), “A knowledge based theory of inter-firm collaborations”, Academy of Management Best Paper Proceedings, pp. 17-21. 
Hart, S., and Tzokas, N. (1999), "The impact of marketing research activity on SME export performance: evidence from the UK”, Journal of Small Business Management, Vol. 37, pp. 63-75.

Hofstede, G. (2001), Culture's Consequences, Comparing Values, Behaviors, Institutions, and Organizations Across Nations, Thousand Oaks CA: Sage Publications.

Hooley, G.J. and Greenley G. (2005), “The resource underpinnings of competitive positions”, Journal of Strategic Marketing, Vol.13 June, pp. 93-116.

Hooley, G.J. and West, D.J. (1984), “The untapped markets for marketing research”, Journal of the Market Research Society, Vol. 26 October, pp. 335-352.

Horn J.L., and McArdle J.J. (1992), “A practical and theoretical guide to measurement Invariance in aging research”, Experimental Aging Research, Vol. 18 No. 3, pp. 117-144.

House R.J., Hanges P.J., Javidan M., Dorfman P.W. and Gupta V. (2004), Culture, Leadership, and Organizations: The GLOBE Study of 62 Societies (Eds.), Sage Publications, Thousand Oaks, CA.

Hult, G.T.M., Ketchen, Jr D.J., Griffith, D.A., Finnegan, C.A., Gonzalez-Padron, T., Harmancioglu, N. Huang, Y. Talay, M.B., and Cavusgil, S.T. (2008), “Data equivalence in cross-cultural international business research: Assessment and guidelines”, Journal of International Business Studies, Vol. 39, pp. 1-18.

Hultman, M., Katsikeas, C.S., and Robson, M.J. (2012), “Export promotion strategy and performance: The role of international experience”, Journal of International Marketing, Vol. 19 No. 4, pp. 17-39.

Hunter, G.L., and Goebel, D.J. (2008), “Salespersons’ information overload: Scale development, validation, and its relationship to salesperson job satisfaction and performance”, Journal of Personal Selling and Sales Management, Vol. 28, No. 1, pp. 21-35. 
Jaworski, B.J. and Kohli, A.K. (1993), “Market orientation: Antecedents and consequences”, Journal of Marketing, Vol. 57, July, pp. 53-70.

Jöreskog, K.G., and Sörbom, D. (1993), LISREL 8: Structural Equation Modeling with the SIMPLIS Command Language, Hillsdale, NJ: Lawrence Erlbaum Associates.

Kaleka, A. (2002), “Resources and capabilities driving competitive advantage in export markets: Guidelines for industrial exporters”, Industrial Marketing Management, Vol. 31 No. 3: pp. 273-283.

Kaleka, A. (2011), "When exporting manufacturers compete on the basis of service: Resources and marketing capabilities driving service advantage and performance”, Journal of International Marketing, Vol. 19 No 1, pp. 40-58.

Kaleka A. and Berthon P. (2006), “Learning and locale: The role of information, memory and environment in determining export differentiation advantage”, Journal of Business Research, Vol. 59, pp. 1016-1024.

Kelloway, E.K. (1998), Using LISREL for Structural Equation Modeling: A Researcher's Guide, Sage.

Knight, G.A. and Cavusgil, S.T. (2004), “Innovation, organization capabilities, and the bornglobal firm”, Journal of International Business Studies, Vol. 35 No. 2, pp. 124-141.

Koh, A.C. (1991), “An evaluation of international marketing research planning in United States export firms”, Journal of Global Marketing, Vol. 4 No. 3, pp. 7-25.

Koh, A.C., Chow, J.S. and Smittivate, S. (1993), “The practice of international marketing research by Thai exporters”, Journal of Global Marketing, Vol. 7 No. 2, pp. 7-26.

Köksal, M.H. (2005), “Sources and types of export information: Insights from Turkish companies”, The Business Review, Vol. 4 No.1, pp. 240-245. 
Leblebici, H. and Salancik, G.R. (1981), "Effects of environmental uncertainty on information and decision processes in banks”, Administrative Science Quarterly, Vol. 26, pp. 578-596.

Lee, J.A. (1966), “Cultural analysis in overseas operations to eliminate the root problem in many business operations”, Harvard Business Review, March-April, pp. 106-114.

Leonidou, L.C. and Theodosiou, M. (2004), “The export marketing information system: an integration of the extant knowledge”, Journal of World Business, Vol. 39, pp. 12-36.

Leonidou, L.C. and Katsikeas, C.S. (1997), “Export information sources: The role of organizational and internationalization influences”, Journal of Strategic Marketing, Vol. 5, pp. 65-87.

Leonidou, L.C., Palihawadana, D. and Theodosiou, M. (2011), “National export-promotion programs as drivers of organizational resources and capabilities: Effects on strategy, competitive advantage, and performance”, Journal of International Marketing, Vol. 19 No. 2, pp. 1-29.

Loane, S., and Bell, J. (2006), "Rapid internationalisation among entrepreneurial firms in Australia, Canada, Ireland and New Zealand: An extension to the network approach” International Marketing Review, Vol. 23 No. 5, pp. 467-485.

Lockett, A. (2009), “Thompson S. Morgenstern U. The development of the resource-based view of the firm: A critical appraisal” International Journal of Management Reviews, Vol.11 No. 1, pp. 9-28.

Lopez, S.V. (2005), “Competitive advantage and strategy formulation: the key role of dynamic capabilities”, Management Decision, Vol. 43 No. 5/6, pp. 661-669.

Lukas, B. A., Whitwell, G. J., and Hill, P. (2007). “Export planning orientation and its antecedents: Evidence from exporting IT products”, Journal of Business Research, Vol. 60, No. 12, pp. 1282-1289. 
McNaughton, R. (2003), “The number of export markets that a firm serves: Process models versus the born global phenomenon” Journal of International Entrepreneurship, Vol. 1, pp. 297-311.

Menon, A. and Varadarajan, P.R. (1992), ”A model of marketing knowledge use within firms” Journal of Marketing, Vol. 56 October, pp. 53-71.

Moorman C. (1995), “Organizational market information processes: cultural antecedents and new product outcomes”, Journal of Marketing Research, Vol. 32, pp. 318-335.

Moorman, C. and Miner, A.S. (1998), “Organizational improvisation and organizational memory”, Academy of Management Review, Vol. 23 No. 4, pp. 698-723.

Morgan, N.A., Zou, S., Vorhies, D.W., and Katsikeas, C.S. (2003), “Experiential and informational knowledge, architectural marketing capability, and adaptive performance of export ventures: A Cross-National Study”, Decision Sciences, Vol. 34 No. 2, pp. 287 - 321.

Morgan, N.A., Katsikeas, C.S., and Vorhies, D.W. (2012), “Export marketing strategy implementation, export marketing capabilities, and export venture performance”, Journal of the Academy of Marketing Science, Vol. 40, pp. 271-289.

Morosini P., Shane S. and Singh H. (1998), “National cultural distance and cross-border acquisition performance”, Journal of International Business Studies, Vol. 29 No.1, pp. 137158.

Mullen, M.R. (1995), “Diagnosing measurement equivalence in cross-national research”, Journal of International Business Studies, Vol. 26 No. 3, pp. 573-596.

Murray, J. Y., Gao, G. Y., Kotabe, M. and Zhou, N. (2007), “Assessing measurement invariance of export market orientation: A study of Chinese and Non-Chinese firms in China”, Journal of International Marketing, Vol. 15 No.4, pp. 41-62.

Narver, J.C., and Slater, S.F. (1990), "The effect of a market orientation on business 
profitability”, Journal of Marketing, Vol. 54 No. 4, pp. 20-35

Navarro, A., Acedo, F.J, Robson, M.J, Ruzo, E., and Losada, F. (2010), “Antecedents and consequences of firms' export commitment: An empirical study”, Journal of International Marketing, Vol. 18, No. 3, pp. 41-61.

Nemkova, E., Souchon, A.L., and Hughes, P. (2012), “Consequences of export decision-making orientation: An exploratory study”, International Marketing Review, Vol. 29 No. 4, pp. 349-378.

Poortinga, Y.H. (1989), “Equivalence of cross-cultural data: An overview of basic issues”, International Journal of Psychology, Vol. 24, pp. 737-756.

Reid, S.D. (1984), “Information acquisition and export entry decisions in small firms”, Journal of Business Research, Vol. 12, pp. 141-157.

Rialp, A. and Rialp, J. (2006), “Faster and more successful exporters: An exploratory study of born global firms from the resource-based view”, Journal of Euromarketing, Vol. 16 No. 1/2, pp. 71-86.

Rindfleisch, A., Malter, A.J. Ganesan, S. and Moorman, C. (2008), “Cross-sectional versus longitudinal survey research: Concepts, findings, and guidelines”, Journal of Marketing Research, Vol. 45, pp. 261-279.

Samiee, S. and Athanassiou, N. (1998), "International strategy research: Cross-cultural methodology implications” Journal of Business Research, Vol. 43 No. 2, pp. 79-96.

Samiee, S. and Walters, P.G.P. (1990), "Influence of firm size on export planning and performance”, Journal of Business Research, Vol. 2, pp. 235-248.

Samiee, S., Walters, P.G.P., and DuBois, F.L. (1993), “Exporting as an innovative behavior: An empirical investigation”, International Marketing Review, Vol. 10, No. 3, pp. 5-25. 
Samiee, S., and Walters, P.G.P. (2002), “Export education: Perceptions of sporadic and regular exporting firms”, International Marketing Review, Vol. 19, No. 1, pp. 80-98.

Schlegelmilch, B.B., Diamantopoulos, A. and Tse, K.Y.K. (1993), “Determinants of export marketing research usage: Testing some hypotheses on UK exporters”, in Baker, M.J. (Ed.), Perspectives on Marketing Management: John Wiley and Sons Ltd, New York. Seringhaus, R.F.H. (1985), “How do major industrial countries support firms' international efforts”, ASAC Conference, Université du Québec à Montréal.

Seringhaus, R.F.H. and Rosson, P.J. (1990), “Export promotion and public organizations: Stateof-the-art”, in Rosson, R.F.H. and P.J. (Eds.), Export Development and Promotion: The Role of Public Organizations, Kluwer Academic Publishers, Norwell, MA, pp. 3-18.

Seringhaus, R.F.H. (1986), “Empirical investigation of awareness, Use and impact of export marketing support by government in manufacturing firms: Contemporary research in marketing”, Proceedings of the $25^{\text {th }}$ Annual Conference of the European Marketing Academy.

Seringhaus, R.F.H. (1987), “The role of information assistance in small firms' export involvement”, International Small Business Journal, Vol. 5 No. 2, pp. 26-36.

Singh, J. (1995), “Measurement issues in cross-national research”, Journal of International Business Studies, Vol. 26, No. 3, pp. 597-619.

Sinkula, J.M. (1990), “Perceived characteristics, organizational factors, and the utilization of external market research suppliers”, Journal of Business Research, Vol. 21, No. 1, pp. 1-17.

Sørensen, H.E. and Madsen, T.K. (2012), “Strategic orientations and export market success of manufacturing firms - The role of market portfolio diversity”, International Marketing Review, Vol. 29 No 4, pp. 424-441. 
Souchon, A.L., Diamantopoulos, A., Holzmüller, H.H. Axinn, C.N., Sinkula, J.M. SimmetBlomberg, H. and Durden, G.R. (2003), “Export information use: A five-country investigation of key determinants”, Journal of International Marketing, Vol. 11 No.3, pp. 106-127.

Souchon, A.L. and Diamantopoulos, A. (1999), "Export information acquisition modes: Measure development and validation”, International Marketing Review, Vol.16 No. 2, pp. 143-168.

Souchon A.L. and Durden, G.R. (2002), "Making the most out of export information: An exploratory study of UK and New Zealand exporters” Journal of Euromarketing, Vol. 11 No. 4, pp. 65-86.

Steenkamp, J-B. E.M. and Baumgartner, H. (1998), “Assessing measurement invariance in crossnational consumer research”, Journal of Consumer Research, Vol. 25 June, pp. 78-90.

Subhadip, R. (2008), “Measuring formative constructs in management research: Definitions, distinctions and measurement”, ICFAI Journal of Management Research, Vol. 7 No. 10, pp. 18-34.

Sy-Changco, J., Souchon, A.L. and Evangelista, F. (2005), “Quality of export memory content: A conceptual framework”, Journal of Marketing Management, Vol. 21 No.3, pp. 291-306.

Teece, D.J., Pisano, G. and Shuen, A. (1997), “Dynamic capabilities and strategic management”, Strategic Management Journal, Vol. 18 No. 7, pp. 509-533.

Theodosiou, M., and Katsikea, E. (2013), “The export information system: An empirical investigation of its antecedents and performance outcomes”, Journal of International Marketing, Vol. 21 No. 3, pp. 72-94.

Toften, K. and Rustan,d K. (2005), “Attributes of information quality of export market assistance: An exploratory study”, European Journal of Marketing, Vol. 39 No. 5/6, pp. 676-698. 
Trompenaars, F. (1993), Riding the Waves of Culture: Understanding Cultural Diversity in Business, McGraw Hill.

UK Trade \& Investment, (2010), http://www.ukti.gov.uk/export/aboutexporting/news/110615.html.

Vernon, I.R. and Ryans, Jr. K.K. (1975), “The awareness and election of an export incentive: The DISC Case”, Baylor Business Studies, Vol. 103, Feb/March/Apr, pp. 19-26.

Wang, X. (2009). Chinese firms’ corporate strategies in the economic downturn. SERI Quarterly, July, pp. 32-39.

Williams, J.E.M. (2003), “Export information use in small and medium-sized industrial companies”, International Marketing Review, Vol. 20, No. 1, pp. 44-66.

Yeoh, P.L. (2000), “Information acquisition activities: A study of global start-up exporting companies”, Journal of International Marketing, Vol. 8 No. 3, pp. 36-60.

Yeoh, P.L. (2005), “A conceptual framework of antecedents of information search in exporting”, International Marketing Review, Vol. 22 No. 2, pp. 165-198.

Zhang, C. Hu, Z. and Gu, F.F. (2008), “Intra- and interfirm coordination of export manufacturers: A cluster analysis of indigenous Chinese exporters”, Journal of International Marketing, Vol. 16 No. 3, pp. 108-135. 
Table 1: Cross-national invariance testing

\begin{tabular}{|l|c|c|c|c|c|c|c|c|c|}
\hline Invariance: & $\chi 2$ & $\mathrm{df}$ & $\operatorname{sig}$ & $\Delta \mathrm{X}^{2}(\mathrm{df})$ & $\mathrm{RMSEA}$ & $\begin{array}{c}\text { Model } \\
\text { CAIC }\end{array}$ & NNFI & CFI & SRMR \\
\hline Configural & 424.025 & 286 & .000 & $\mathrm{~N} / \mathrm{A}$ & .048 & 2957.560 & .931 & .962 & .045 \\
\hline $\begin{array}{l}\text { Partial } \\
\text { metric }\end{array}$ & 436.891 & 294 & .000 & $\begin{array}{c}12.866 \\
(8) \\
< \\
\text { critical } \\
\text { value } \\
(15.507)\end{array}$ & .049 & 2910.987 & .931 & .960 & .046 \\
\hline $\begin{array}{l}\text { Factor } \\
\text { variance }\end{array}$ & 486.672 & 264 & $.000 \begin{array}{c}49.781 \\
(30) \\
> \\
\text { critical } \\
\text { value } \\
(43.773)\end{array}$ & .064 & 2737.877 & .903 & .944 & .067 \\
\hline
\end{tabular}


Table 2: Model testing

\begin{tabular}{|c|c|c|c|c|c|c|c|c|c|c|c|}
\hline & $x^{2}$ & $\mathrm{df}$ & sig & $\Delta \chi^{2}$ & $\Delta \mathrm{df}$ & sig & RMSEA & $\begin{array}{l}\text { Model } \\
\text { CAIC }\end{array}$ & NNFI & CFI & SRMR \\
\hline $\begin{array}{l}\text { Model } 1 \\
\text { No quadratics } \\
\text { Fully invariant }\end{array}$ & 644.32 & 365 & 0 & & & & 0.060 & 2145.12 & 0.77 & 0.82 & 0.078 \\
\hline $\begin{array}{l}\text { Model } 2 \\
\text { Quadratics } \\
\text { Fully invariant }\end{array}$ & 579.69 & 347 & 0 & $\begin{array}{c}-64.63 \\
\quad> \\
\text { critical } \\
\text { value } \\
28.87)\end{array}$ & 18 & $\begin{array}{c}\text { Sig } \\
\text { decrease } \\
\text { in } \chi^{2}\end{array}$ & 0.057 & 2214.23 & 0.79 & 0.84 & 0.077 \\
\hline $\begin{array}{l}\text { Model } 3 \\
\text { Quadratics } \\
\text { Fully variant }\end{array}$ & 448.32 & 249 & 0 & $\begin{array}{c}-131.38 \\
\quad> \\
\text { critical } \\
\text { value } \\
122.108 \\
)\end{array}$ & 98 & $\begin{array}{c}\text { Sig } \\
\text { decrease } \\
\text { in } \chi^{2}\end{array}$ & 0.062 & 2810.97 & 0.76 & 0.87 & 0.068 \\
\hline $\begin{array}{l}\text { Model } 4 \\
\text { Quadratics } \\
\text { Variant paths }\end{array}$ & 510.99 & 327 & 0 & $\begin{array}{c}-68.70 \\
(> \\
\text { critical } \\
\text { value } \\
31.41)\end{array}$ & 20 & $\begin{array}{c}\text { Sig } \\
\text { decrease } \\
\text { in } \chi^{2}\end{array}$ & 0.052 & 2294.12 & 0.82 & 0.87 & 0.072 \\
\hline
\end{tabular}




\section{Table 3: Path coefficients}

\begin{tabular}{|c|c|c|c|c|c|c|c|c|c|c|c|c|}
\hline & $\begin{array}{c}\text { All } \\
\text { samples }\end{array}$ & US & Austria & NZ & $\begin{array}{c}\text { All } \\
\text { samples }\end{array}$ & US & Austria & $\mathrm{NZ}$ & $\begin{array}{c}\text { All } \\
\text { samples }\end{array}$ & US & Austria & NZ \\
\hline & \multicolumn{12}{|c|}{$\begin{array}{c}\text { Standardized parameter estimates } \\
\text { (t-values) }\end{array}$} \\
\hline \multicolumn{2}{|c|}{ Knowledge $R^{2}$} & .17 & .28 & .20 & & & & & & & & \\
\hline Experience (H1) & $\begin{array}{c}0.13 \\
(2.30) \\
\end{array}$ & & & & & & & & & & & \\
\hline Complexity (H2) & $\begin{array}{c}0.30 \\
(5.18)\end{array}$ & & & & & & & & & & & \\
\hline Specificity (H3) & $\begin{array}{c}0.12 \\
(2.12)\end{array}$ & & & & & & & & & & & \\
\hline \multirow[t]{2}{*}{ Size (control) } & & $\begin{array}{c}-0.12 \\
(-1.24) \\
\end{array}$ & $\begin{array}{c}0.14 \\
(1.76)\end{array}$ & $\begin{array}{c}0.01 \\
(0.06) \\
\end{array}$ & & & & & & & & \\
\hline & $E M R R^{2}$ & .30 & .38 & .28 & $E A R^{2}$ & .42 & .30 & .22 & $E M I R^{2}$ & .69 & .56 & .54 \\
\hline Knowledge (H4) & $\begin{array}{l}0.19 \\
(3.50)\end{array}$ & & & & $\begin{array}{c}0.26 \\
(5.03)\end{array}$ & & & & $\begin{array}{l}0.10 \\
(2.28)\end{array}$ & & & \\
\hline Experience (H5) & & $\begin{array}{c}-0.12 \\
(-1.15)\end{array}$ & $\begin{array}{c}0.11 \\
(1.31)\end{array}$ & $\begin{array}{c}-0.10 \\
(-1.24)\end{array}$ & $\begin{array}{l}-0.05 \\
(-0.89)\end{array}$ & & & & & $\begin{array}{c}-0.07 \\
(-0.85)\end{array}$ & $\begin{array}{c}-0.17 \\
(-1.94) \\
\text { opp dir }\end{array}$ & $\begin{array}{c}0.03 \\
(0.36)\end{array}$ \\
\hline Experience $^{2}(\mathrm{H} 6)$ & $\begin{array}{c}-0.03 \\
(-0.59)\end{array}$ & & & & $\begin{array}{c}0.03 \\
(0.62) \\
\end{array}$ & & & & $\begin{array}{c}-0.01 \\
(-0.12)\end{array}$ & & & \\
\hline Complexity (H7) & $\begin{array}{c}0.15 \\
(1.27) \\
\end{array}$ & & & & $\begin{array}{c}0.19 \\
(1.82)\end{array}$ & & & & & $\begin{array}{c}0.51 \\
(3.79)\end{array}$ & $\begin{array}{c}0.47 \\
(3.39)\end{array}$ & $\begin{array}{c}0.23 \\
(1.95)\end{array}$ \\
\hline Complexity $^{2}$ (H8) & $\begin{array}{c}-0.17 \\
(-3.35)\end{array}$ & & & & $\begin{array}{c}-0.13 \\
(-2.88)\end{array}$ & & & & $\begin{array}{c}-0.06 \\
(-1.60)\end{array}$ & & & \\
\hline Specificity (H9) & $\begin{array}{r}0.24 \\
(3.60)\end{array}$ & & & & & $\begin{array}{r}0.43 \\
(4.51)\end{array}$ & $\begin{array}{r}0.19 \\
(2.14)\end{array}$ & $\begin{array}{c}0.11 \\
(1.35)\end{array}$ & $\begin{array}{c}0.17 \\
(3.60)\end{array}$ & & & \\
\hline Dependence (H10) & $\begin{array}{c}-0.01 \\
(-0.12)\end{array}$ & & & & $\begin{array}{c}-0.07 \\
(-0.87)\end{array}$ & & & & & $\begin{array}{c}0.24 \\
(1.96) \\
\end{array}$ & $\begin{array}{c}0.09 \\
(0.79) \\
\end{array}$ & $\begin{array}{c}0.27 \\
(2.63)\end{array}$ \\
\hline Dependence $^{2}$ (H11) & $\begin{array}{c}-0.06 \\
(-1.06)\end{array}$ & & & & & $\begin{array}{c}0.08 \\
(0.94)\end{array}$ & $\begin{array}{c}-0.17 \\
(-2.15)\end{array}$ & $\begin{array}{c}0.14 \\
(1.93) \\
\text { opp dir }\end{array}$ & $\begin{array}{c}-0.10 \\
(-2.74)\end{array}$ & & & \\
\hline $\begin{array}{l}\text { Technological } \\
\text { turbulence (H12) }\end{array}$ & $\begin{array}{c}0.11 \\
(1.96)\end{array}$ & & & & $\begin{array}{c}0.01 \\
(0.03) \\
\end{array}$ & & & & $\begin{array}{c}0.04 \\
(0.95) \\
\end{array}$ & & & \\
\hline $\begin{array}{l}\text { Competitive } \\
\text { intensity (H12) }\end{array}$ & $\begin{array}{c}-0.03 \\
(-0.66) \\
\end{array}$ & & & & $\begin{array}{c}0.02 \\
(0.43) \\
\end{array}$ & & & & & $\begin{array}{c}-0.01 \\
(-0.06) \\
\end{array}$ & $\begin{array}{c}0.23 \\
(3.28)\end{array}$ & $\begin{array}{c}-0.02 \\
(-0.28) \\
\end{array}$ \\
\hline
\end{tabular}




\begin{tabular}{|c|c|c|c|c|c|c|c|c|c|}
\hline $\begin{array}{l}\text { Market } \\
\text { dynamism (H12) }\end{array}$ & & $\begin{array}{c}-0.10 \\
(-0.96)\end{array}$ & $\begin{array}{c}-0.12 \\
(-1.37)\end{array}$ & $\begin{array}{c}0.13 \\
(1.56)\end{array}$ & $\begin{array}{c}0.06 \\
(1.07) \\
\end{array}$ & & $\begin{array}{c}-0.12 \\
(-1.53)\end{array}$ & $\begin{array}{c}-0.11 \\
(-1.34)\end{array}$ & $\begin{array}{c}0.20 \\
(2.98) \\
\end{array}$ \\
\hline $\begin{array}{l}\text { Technological } \\
\text { turbulence }{ }^{2}(\mathrm{H} 13)\end{array}$ & $\begin{array}{l}-0.05 \\
(-0.95)\end{array}$ & & & & $\begin{array}{c}-0.02 \\
(-0.41)\end{array}$ & $\begin{array}{c}0.01 \\
(0.09)\end{array}$ & & & \\
\hline $\begin{array}{l}\text { Competitive } \\
\text { intensity }^{2}(\mathrm{H} 13)\end{array}$ & $\begin{array}{c}-0.02 \\
(-0.48)\end{array}$ & & & & $\begin{array}{c}-0.04 \\
(-0.95)\end{array}$ & $\begin{array}{c}-0.06 \\
(-1.66)\end{array}$ & & & \\
\hline $\begin{array}{l}\text { Market } \\
\text { dynamism }^{2} \text { (H13) }\end{array}$ & $\begin{array}{c}0.01 \\
(0.26)\end{array}$ & & & & $\begin{array}{c}0.01 \\
(0.10)\end{array}$ & $\begin{array}{c}0.05 \\
(1.25)\end{array}$ & & & \\
\hline Size (control) & $\begin{array}{c}0.17 \\
(2.88)\end{array}$ & & & & $\begin{array}{c}0.01 \\
(0.25)\end{array}$ & $\begin{array}{c}0.01 \\
(0.03) \\
\end{array}$ & & & \\
\hline
\end{tabular}

Key:

EMR: Export Marketing Research

\section{EA: Export Assistance}

EMI: Export Market Intelligence 
Figure 1: Antecedents to Export Information Generation

\begin{tabular}{|c|c|c|c|c|}
\hline Export experience & \multicolumn{3}{|c|}{$\mathrm{H} 5,6(+) \& \mathrm{H} 7,8(+/-)$} & \\
\hline Export complexity & $\mathrm{H} 1,2(+)$ & \multirow{2}{*}{$\begin{array}{l}\text { Knowledge of export } \\
\text { information sources }\end{array}$} & $I_{-1}$ & Export marketing research \\
\hline \multirow[b]{2}{*}{ Export specificity } & H3 (+) & & \multirow[b]{2}{*}{$\mathrm{H} 9(+)$} & \\
\hline & & & & Export assistance \\
\hline Export dependence & & \multicolumn{2}{|c|}{$\mathrm{H} 10(+) \& \mathrm{H} 11(+/-)$} & \\
\hline Environmental turbulence & & \multicolumn{2}{|c|}{$\mathrm{H} 12(+) \& \mathrm{H} 13(+/-)$} & Export market intelligence \\
\hline
\end{tabular}




\section{Appendix 1: Sample descriptives}

\begin{tabular}{|l|c|c|c|c|c|c|}
\hline & \multicolumn{3}{|c|}{ Mean } & \multicolumn{3}{c|}{ Standard deviation } \\
\hline & US & Austria & NZ & US & Austria & NZ \\
\hline Number of employees & 1538.24 & 620.77 & 232.75 & 7530.31 & 1105.46 & 509.18 \\
\hline Export complexity & 4.49 & 4.36 & 3.42 & 2.34 & 2.41 & 1.99 \\
\hline Export dependence & 14.92 & 52.28 & 45.96 & 17.67 & 32.21 & 32.50 \\
\hline Export experience & 21.50 & 32.69 & 17.60 & 19.23 & 29.95 & 15.63 \\
\hline
\end{tabular}




\section{Appendix 2: Operationalizations}

\section{Export information generation (on a 5-point frequency scale)}

Export Marketing Research:

How often does your company

- conduct export marketing research in-house?

- purchase export marketing research data which is sold on a subscription basis?

- commission export marketing research projects to be carried out specifically for the company by independent marketing research agencies?

\section{Export Assistance:}

How often do you use the following export assistance bodies to obtain export information?

- Trade associations

- Export associations/clubs

- Banks

- Trade missions

- Conferences/seminars on exporting

Export Market Intelligence:

How often do you obtain information from the following export market intelligence sources?

- Your company's own staff abroad

- Contacts with or visits to export customers

- Contacts with or visits to export agents/distributors

\section{Export Experience:}

- How long (in years) has your firm been exporting?

\section{Export Complexity:}

- To how many countries does your company export?

\section{Export Specificity:}

- Does your firm have a separate export department? [yes/no]

\section{Environmental Turbulence (on a 5-point Likert scale)}

Technological Turbulence:

- The technology in our industry is changing rapidly

- Technological changes provide big opportunities in our industry

- A large number of new product ideas have been possible through technological breakthroughs in our industry

- Technological developments in our industry are rather minor (reverse coded)

Competitive Intensity:

- Anything that one competitor can offer, others can match rapidly

- Price competition is a hallmark of our industry

- Aggressive selling is the norm in our industry 


\section{Market Dynamism:}

- In our kind of business, customers' product preferences change quite a bit over time

- Our customers tend to look for new products all the time

- New customers tend to have product-related needs that are different from those of our existing customers

\section{Knowledge of export information sources (on a 5-point Likert scale):}

- In our company, we are very aware of information sources available to exporters 
Appendix 3: Squared Correlations, Construct Reliability, Average Variance Extracted

\begin{tabular}{|c|c|c|c|c|}
\hline & $\mathbf{C R}$ & TEC & COMP & CUS \\
\hline \multicolumn{5}{|l|}{ US } \\
\hline TEC & .88 & .59 & & \\
\hline COMP & .73 & .008 & .48 & \\
\hline CUS & .70 & .105 & .035 & .53 \\
\hline \multicolumn{5}{|l|}{ Austria } \\
\hline TEC & .85 & .52 & & \\
\hline COMP & .75 & .000 & .51 & \\
\hline CUS & .69 & .152 & .001 & .54 \\
\hline \multicolumn{5}{|c|}{ New Zealand } \\
\hline TEC & .88 & .58 & & \\
\hline COMP & .74 & .004 & .49 & \\
\hline CUS & .78 & .089 & .000 & .64 \\
\hline
\end{tabular}

Note: Average variance extracted is provided on the diagonal. $\mathrm{CR}=$ Composite reliability.

TEC: technological turbulence

COMP: competitive intensity

CUS: market dynamism 
Appendix 4: Correlation tables

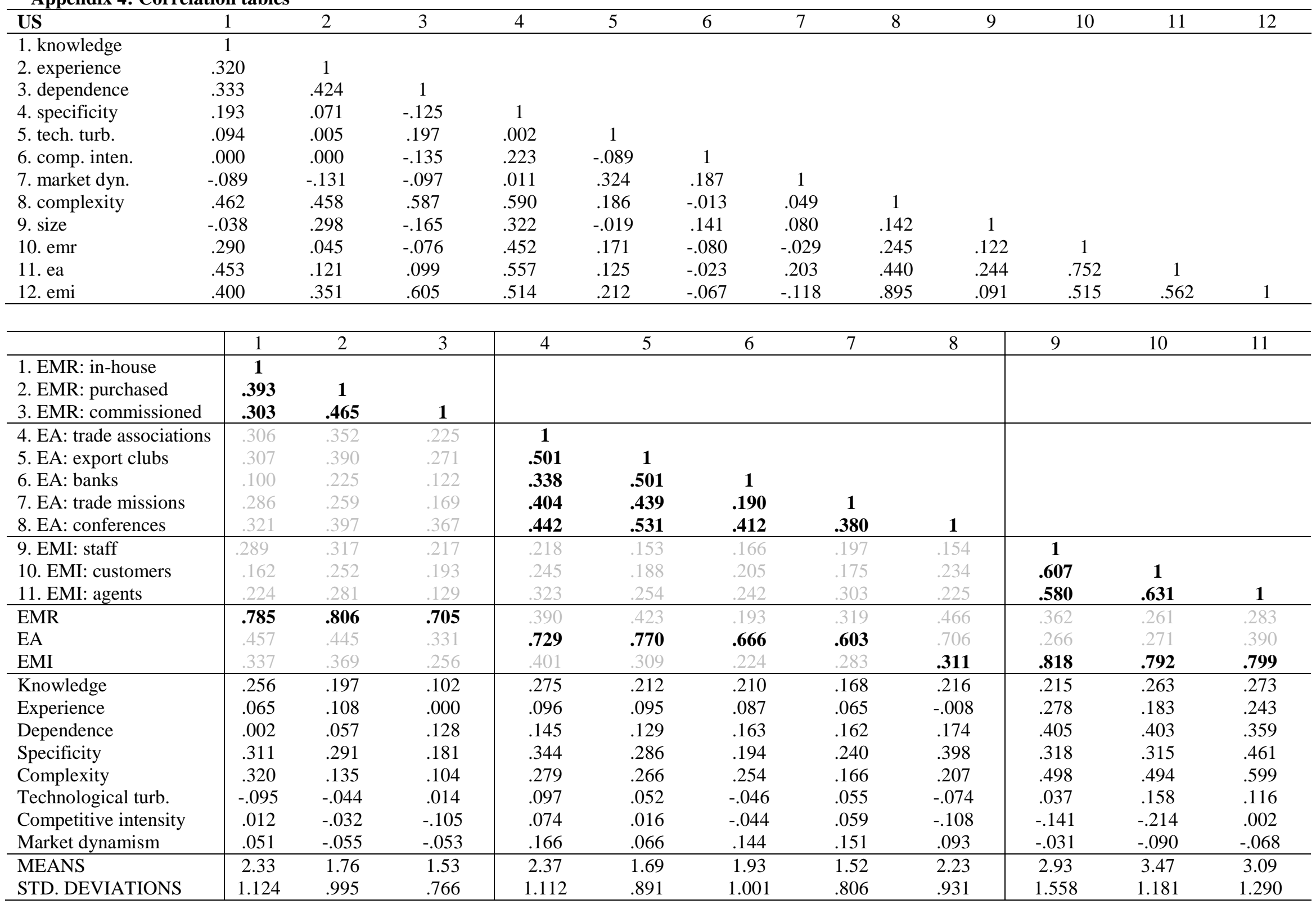




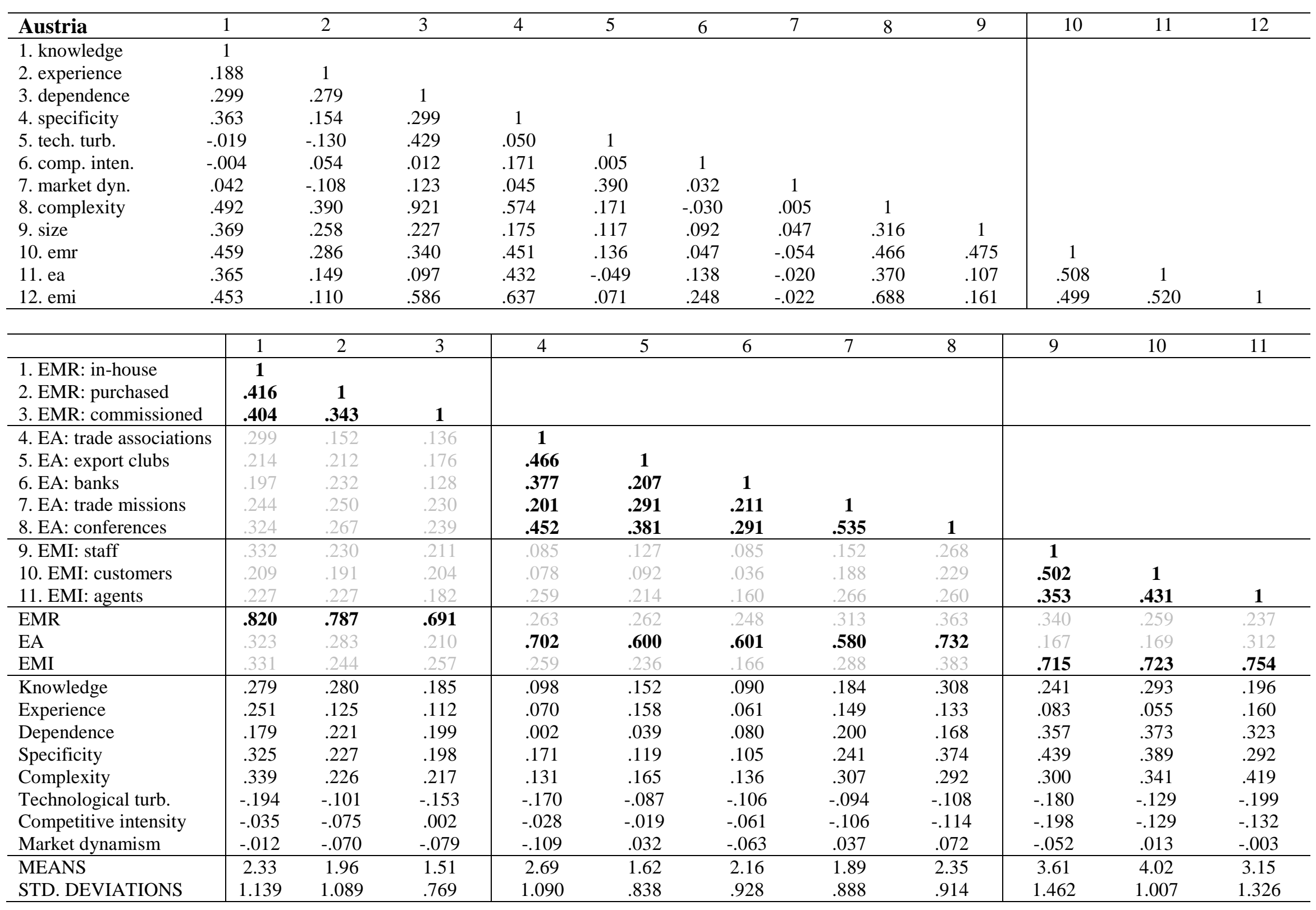




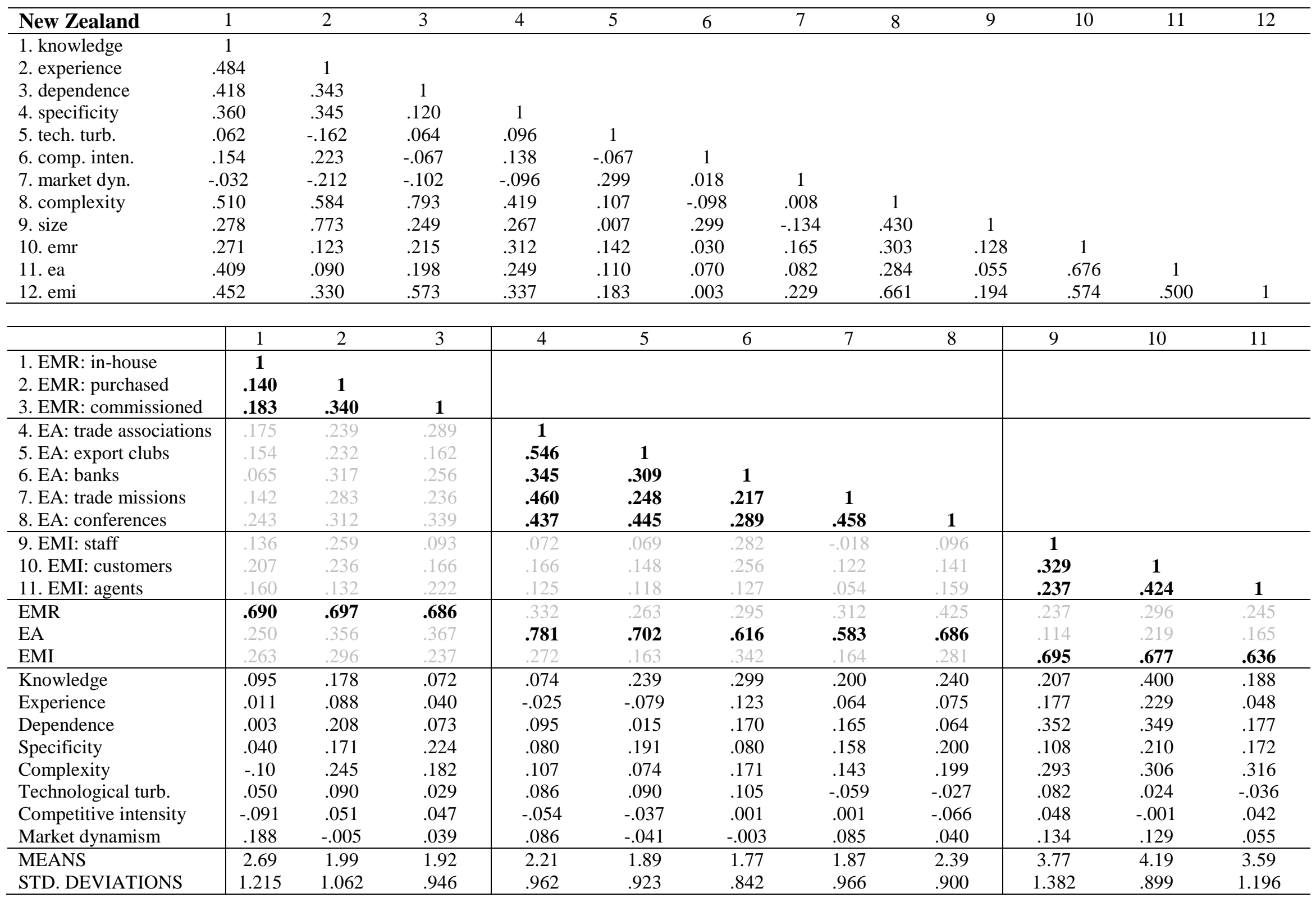


